\title{
KELSEN AND CONTEMPORARY CONSTITUTIONALISM: THE CONTINUED PRESENCE OF KELSENIAN THEMES*
}

\author{
Kelsen y constitucionalismo contemporáneo: \\ la continua presencia de los temas kelnesianos
}

\author{
Paolo Carrozza ${ }^{1}$ \\ Full Professor of Constitutional Law \\ Scuola Superiore Sant'Anna, Pisa \\ paolo.carrozza@sssup.it
}

http://dx.doi.org/10.18543/ed-67(1)-2019pp55-82

Recibido: 11.05.2019

Aceptado: 21.06.2019

\begin{abstract}
This chapter aims to demonstrate the enduring importance of Kelsen's thought in contemporary constitutionalism and contends that constitutionalists are considerably more Kelsenian than generally supposed. The chapter commences with a short reconstruction of three different periods in Kelsen's legal thought: his contribution to Vienna law school under the influence of the German positivism; Kelsen's commitment, from 1918 to 1933, to the newly-born Austrian republic; his forced emigration to the U.S.A. in 1940 and his encounter with the American school of law and political
\end{abstract}

* Cómo citar / Citation 'Chicago-Deusto' (Autor-fecha / Author-date / Lista de referencias / Reference list entries): Carrozza, Paolo. 2019. "Kelsen and Contemporary Constitutionalism: The Continued Presence of Kelsenian Themes". Estudios de Deusto 67, n. ${ }^{\circ}$ 1: 55-82. http://dx.doi.org/10.18543/ed-67(1)-2019pp55-82.

${ }^{1}$ Full Professor of Constitutional Law, Scuola Superiore Sant'Anna, Pisa. This piece was originally published in an edited volume: Peter Langford, Ian Bryan and John McGarry (eds), Kelsenian Legal Science and the Nature of Law (Berlin, Springer, 2017) 75-98. in E-mail: paolo.carrozza@sssup.it 
science. Kelsen's contribution to contemporary constitutionalism begins with the great influence of his thought on the Austrian Constitution of 1920, which Kelsen defended in newspaper articles as well as in scholarly papers. The chapter maintains that Kelsenian legal science has continuing significance in two main fields of contemporary constitutionalism, both originated by the consideration of the constitution as a higher law: the first, the Austrian model for the judicial review of legislation, which shaped the European model of constitutional adjudication, nowadays diffused throughout the world; and the second, the 'gradualist' theory of the sources of law (the Stufenbau). It is argued that Kelsen's legal thought has enduring import in the present-day crisis of constitutionalism not only for the legal understanding of multi-level government (monism v. dualism) but also for the globalization of constitutionalism and the idea of open-ended constitutionalism.

\section{Keywords}

Constitutional Law; Kelsen; globalization; multi-level government.

\section{Resumen}

Este capítulo pretende demostrar la importancia perdurable del pensamiento de Kelsen en el constitucionalismo contemporáneo y sostiene que los constitucionalistas son considerablemente más kelsenianos de lo que generalmente se supone. El capítulo comienza con una breve reconstrucción de tres períodos diferentes en el pensamiento legal de Kelsen: su contribución a la Escuela de Derecho de Viena bajo la influencia del positivismo alemán; El compromiso de Kelsen, desde 1918 hasta 1933, hacia la república austriaca recién nacida; su emigración forzada a los EE. UU. en 1940 y su encuentro con la escuela estadounidense de derecho y ciencias políticas. La contribución de Kelsen al constitucionalismo contemporáneo comienza con la gran influencia de su pensamiento en la Constitución austriaca de 1920, que Kelsen defendió en artículos periodísticos y en estudios académicos. El capítulo sostiene que la ciencia jurídica kelseniana tiene una importancia continua en dos campos principales del constitucionalismo contemporáneo, ambos originados por la consideración de la constitución como una ley superior: el primero, el modelo austriaco para la revisión judicial de la legislación, que dio forma al modelo europeo de la adjudicación constitucional, hoy en día difundida en todo el mundo; y la segunda, la teoría «gradualista» de las fuentes del derecho (la Stufenbau). Se argumenta que el pensamiento legal de Kelsen tiene una importancia perdurable en la crisis actual del constitucionalismo, no solo para la comprensión legal del gobierno multinivel (monismo contra dualismo) sino también para la globalización del constitucionalismo y la idea de apertura. Terminó el constitucionalismo.

\section{Palabras clave}

Derecho Constitucional; Kelsen; globalización; gobernanza multinivel. 


\begin{abstract}
SUMARIO: I. INTRODUCTION. II. THE PERTINENCE OF IDENTIFYING THREE DIFFERENT PERIODS IN THE HISTORY OF HANS KELSEN'S LEGAL THOUGHT. 1. The contribution of the Vienna school marked by the influence of German positivist legal thought. 2. Kelsen's commitment to the newborn Austrian republic (from 1918 to 1933). 3. The forced emigration to the U.S.A.: Kelsen and the problem of democracy. III. KELSEN'S GOLDEN AGE AND His CONTRIBUTION TO CONTEMPORARY CONSTITUTIONALISM. 1. A committed jurist: the influence of Kelsen's thought on the Austrian constitution of 1920 and its defense. 2. The constitution as a higher law and its consequences. 2.1. The judicial review of legislation: at the origins of the european model of constitutional adjudication. 2.2. The gradualist theory of the sources of law: the stufenbau. IV. KELSEN AND POST-MODERN CONSTITUTIONALISM. 1. The importance of Kelsen's thought for the legal understanding of multi-level government (monism v. dualism). 2. The globalization of constitutionalism: is an open- ended constitutionalism possible?
\end{abstract}

\title{
I. INTRODUCTION
}

The aim of this chapter is to demonstrate that contemporary jurists and lawyers are much more Kelsenian than generally supposed. They remain more Kelsenian than legal and moral philosophers or political scientists particularly when discussing the unconstitutional character of a law; the ascendency of the superior norm over the subordinate norm; or the jurisdiction of a region or member state (i.e., whether a certain regional norm is valid or not). For a significant body of academic work, the legacy of Kelsen's thought is very important for the growth and elaboration of the European model of the judicial review of legislation ${ }^{2}$ and for the study of the sources of law. Indeed, few would deny that Kelsen's legal philosophy has a critical place in the field of legal reasoning. This appears true especially when considering the challenges to legal thought and reasoning posed by both the functioning of supranational legal orders and by the pluralism typical of the era of globalization, regardless of the often justified criticism concerning the Kelsenian methodological project to elaborate a "pure" theory of law and the many difficulties and ambiguities arising from his purported formalism and the philosophical foundation of his work.

2 Pedro Cruz Villalón, «La formación del sistema Europeo de control de constitucionalidad (1918- 1939)» (1987) Centro de Estudios Constitucionales, 341 et seq.; Alessandro Pizzorusso, «I sistemi di giustizia costituzionale: dai modelli alla prassi» (1982) Quaderni costituzionali 521, 527 et seq.; Mauro Cappelletti, Il controllo giudiziario di costituzionalità delle leggi nel diritto comparato (Milano, Giuffrè, 1973) 101 et seq. 


\section{THE PERTINENCE OF IDENTIFYING THREE DIFFERENT PERIODS IN THE HISTORY OF HANS KELSEN'S LEGAL THOUGHT}

The Vienna School, which emerged in a brief period of existence of the First Austrian Republic, represents a particularly distinctive and significant body of theoretical work concerning law and politics. The School, while centred upon Kelsen, included other important jurists such as Josep Kunz, Felix Kaufmann, Fritz Sander, Fritz Schreier, Adolf Merkl, and Alfred von Verdross, also known as the jungösterreichische Schule. ${ }^{3}$ The School can be considered to represent a centrally important movement or tendency in continental European legal thought which extends beyond the particular field of constitutional law. An engagement with the work of the Vienna School reveals the influence of Carl Friedrich von Gerber, Paul Laband and Georg Jellinek and the development of a form of legal positivism which breaks with the preceding German tradition of legal positivism of the final decades of the nineteenth century.

\section{The Contribution of the Vienna School Marked by the Influence of German Positivist Legal Thought}

From the perspective of constitutional and public law, the principal contribution of the Vienna School, and of Kelsen's thought in particular, was the sharpening of the existing German positivist legal method in public and constitutional law; this was an abstract and conceptual construction to which Kelsen brought coherence and a logical perfection that remained unsurpassed by the same German scholars. In the second half of the nineteenth century, legal thinking in Germany reflected the ascendancy of positivist method and philosophy: any science and, thus, also law, has its method and this method is governed by principles and concepts elaborated by the logical construction of general and dogmatic rules. These rules, which typify each science, have to be distinguished - methodologically purified - from the rules that govern the other sciences: hence legal reasoning, as the basis for the construction of an autonomous legal science, must be purified of all political, historical and sociological conceptions. The autonomy of a distinctively legal science from the other sciences is then definitively established.

It is pertinent to pose the question of why this originated in Germany and Vienna, and not in France, Italy or Spain, where the German Legal Method

${ }^{3}$ Erhard Mock, «Rechtsphilosophie und Rechtsphilosophen an der Wiener Juristenfacultät» (1970) $20 \square$ sterrreichische Zeitschrift für $\square$ ffentliches Recht 373; Mario Patrono, «Presentazione», in Adolf Julius Merkl, Mario Patrono, Carlo Geraci and Wolff Dietrich Grussmann (eds), Il duplice volto del diritto: il sistema kelseniano e altri saggi. (Milano, Giuffré, 1987), viii. 
was later exported. It is possible to respond on the basis of two main reasons. The first, a historical reason: the initial political division and fragmentation of Germany (into around 40 small states), the concomitant need for establish both political and legal unification in which the reconductio ad unitatem of the legal order is the main framework of Recht Methoden. The second is situated in the development of a positivist approach to reasoning in the legal sciences, not only in public law, but also in civil law and administrative law; and the subsequent exportation of this model of legal thought to Italy, Spain and other countries. The development gave rise to a particular tradition in the history of law, the so-called Roman-German tradition. ${ }^{4}$

The definition and delineation of the typical functions of the state (legislative, executive and judiciary) and of the state as a legal order (ordinamento giuridico, Rechtsordnung, legal system) were the most important achievements of such German legal positivist scholars as von Gerber, Laband and Jellinek. Kelsen and the Vienna School contributed to this tradition with the idea of the constitution as higher law and with the idea of a hierarchical and competency relationship between legal norms (from constitutional norms to parliamentary legislation to administrative regulation and concrete acts, both legal judgments and administrative acts): the Stufenbau or gradualist theory of norms. Here, a hierarchical ordering of norms, based upon the necessity of the interconnection of the sources of law with each other, thereby entailing that respect for the superior (and more general) provision is the condition of validity of the inferior (and more concrete) provision. These are the most important aspect of Kelsen's constitutional thought. Although these elements of Kelsen's constitutional thinking are already prefigured in his 1911 Hauptprobleme der Staatsrechtslehre ${ }^{5}$ they were only provided with a more comprehensive and sophisticated presentation after World War I, during the period of the new Austrian Republic.

\section{Kelsen's Commitment to the Newborn Austrian Republic} (From 1918 to 1933)

In 1919 Hans Kelsen was engaged by the Austrian Premier Karl Renner in order to write some aspects of the new republican constitution and to

${ }^{4}$ See René David, I grandi sistemi giuridici contemporanei (Padova, Cedam, 1973) 29 et seq.; Konrad Zweigert and Hein Kötz, Introduzione al Diritto comparato (Milano, Giuffrè, 1998) 164 et seq. This is a tradition that has been studied deeply by these famous comparativists within the field of private law. However, the tradition has, in contrast, received less attention within the field of public law (see, for example, in relation to Italian administrative law, Sabino Cassese, Cultura e politica del diritto amministrativo (Bologna Il Mulino, 1971).

${ }_{5}$ Hans Kelsen, Hauptprobleme der Staatsrechtslehere entwickelt aus der Lehre vom Rechtssatze (Tübingen, J.C.B. Mohr, 1911). 
participate in the work of the constituent assembly. It is generally held that Kelsen's legal theories had a substantial influence on the Austrian constitution of 1920: the predominant interpretation of the relationship between Kelsenian legal science and the Austrian constitution of 1920 is of a direct and unmediated reflection of the application of Kelsenian legal science. ${ }^{6}$ It is possible, however, in contrast to this prevailing position, to consider the relationship as a more complex process in which, after the defeat and collapse of the Hapsburg Empire, the political conflict and negotiation between the Christian Democrat party and the Socialist party at the founding of the Austrian Republic, actively contributed to important modifications and alterations to the initial Kelsenian approach to the conception of a constitutional framework. The effect of this political conflict finds juridical reflection in the federal solution (the compromise between the 'red' Vienna and the 'white' Länder of German-speaking Austria); the call for unity and negotiation between the two major parties in establishing new constitutional rules; and the electoral struggle between the same two parties, which was an obstacle in the elaboration and selection of these rules, given that the two major parties had contrasting ideologies and programmes. The overarching contribution of all these factors led to the formulation of a difficult juridical 'compromise' which was probably at the origin of Kelsen's idea of a value-free constitution: the constitution as a system of norms whose function is to establish and to control the fundamental powers and functions of the state and, thus, neither a political programme nor the mere translation of a political ideology into legal norms.

The difficulties encountered in the legislative implementation of constitutional provisions, in transforming the 'long' and complex European postWorld War II constitutions into positive and legislative norms, and the implementation of constitutional norms inspired by different and sometimes contradictory principles advocated by diverse constituent parties became the central drama arising from such explicitly value-oriented constitutions as Italy's and, to a certain extent Germany's, following the defeat of Fascism and Nazism, and later with those of Spain and Portugal. ${ }^{7}$ The compromise among different political parties and interest groups, each engaging in a direct trans-

${ }^{6}$ See, Thomas Olechowski, «Der Beitrag Hans Kelsens zur österreichischen Bundesverfassung», in Robert Walter, Werner Ogris and Thomas Olechowski (eds), Hans Kelsen: Leben - Werk - Wirksamkeit (Vienna, Manz, 2009) 212 et seq.; Theo Öhlinger, «The Genesis of the Austrian Model of Constitutional Review of Legislation» (2003) 16 Ratio Juris 2: 206-222, 206 et seq.; Georg Schmitz,. Die Vorentwürfe Hans Kelsens für die österreichische Bundesverfassung (Wien, Manz, 1981).

${ }^{7}$ For the distinction between 'short' and 'long' constitutions, see Piero Calamandrei, Questa nostra costituzione (Milano, Bompiani) 6. 
lation of its own ideology and political programme into constitutional norms, becomes effectively inoperative, within the constitutional framework, when this has, as its object, norms concerning the economic regime or welfare rights and even fundamental rights, so that it is then necessary to establish a hierarchy among those rights and norms in order to resolve a case, to engage in constitutional adjudication, or, in short, to remain capable of applying and interpreting legal rules.

If the enforcement of constitutional norms regarding welfare rights and the economic regime is mainly a political question, the first significant legacy of Kelsenian thought for contemporary constitutionalism (and for the many 'long' European constitutions) is that constitutional norms should be considered, firstly, as norms and, thus, that they should be accorded this status by interpreters (such as judges but also citizens, public servants and so on) as such, thereby giving effect to their whole significance and their legal content in the process of legal interpretation. This, in turn, requires the adoption of both a process of constructive interpretation and a process of concrete application of the norms to the facts. ${ }^{8}$

The second significant legacy of Kelsenian thought of this period is the idea of parliamentarism. The ideas of a parliamentary republic and a purely parliamentary form of government were the subject of explicit theoretical reflection, by Kelsen, in several important essays on the relations among political parties, democracy and parliamentarism. ${ }^{9}$ This theoretical work was subsequently combined with Kelsen's involvement in the public constitutional debate, through various pamphlets against the 1929 reform of the Austrian Constitution, defined as semi-fascist, until he broke definitively with the new nationalist government, and voluntarily abandoned Austria. There is a great modernity in this double commitment - the legal scholar and pamphleteer - the emphasis upon the equally important task of public intervention, debate and education regarding the meaning and the risks of the 1929 constitutional reform. ${ }^{10}$

${ }^{8}$ See Paolo Barile, La Costituzione come norma giuridica (Firenze, Barbèra, 1951); Eduardo Garcìa de Enterrìa, La Constitución como norma y el Tribunal Constitucional (Madrid, Editorial Civitas, 1981).

9 See Hans Kelsen, Vom Wesen und Wert der Demokratie (Tübingen, J.C.B. Mohr, 1920); Hans Kelsen, Das Problem des parlamentarismus (Vienna/Leipzig, Braumüller, 1925).

${ }^{10}$ Kelsen was, perhaps, the first jurist sought to intervene in the existing political debate through both the form of newspaper articles and form of academic writing in the form of books, article and reviews. See Hans Kelsen «Der Drang zur Verfassungsreform» (October 6th, 1929) Neue Freie Presse; Hans Kelsen, «Die Grundzüge der Verfasssungsreform (I)» (October 20th, 1929) Neue Freie Presse; Hans Kelsen, «Die Grundzüge der Verfasssungsreform (II)», (October 30th, 1929) Neue Freie Presse. 


\section{The Forced Emigration to the U.S.A.: Kelsen and the Problem of Democracy}

During the years spent at Harvard and Berkeley, Kelsen's engagement and conceptual framework produces work which is comparatively less substantial than that of the period prior to emigration. In the U.S.A., Kelsen compared his own theories with American common law principles and constitutional philosophies; however, in the most relevant and significant work of this period ${ }^{11}$ indicates that, from the perspective of constitutional theory, the confrontation with the American academic tradition has the effect of rendering his theoretical framework more ambiguous and contradictory than in the previous writings. ${ }^{12}$

On the other hand, the distinctive case-based method dominating American constitutional law (until the profound transformation introduced by the Harvard Law School scholar Lawrence Tribe in his famous handbook - and not casebook, ${ }^{13}$ was accompanied by the attendant difficulty of American scholars to engage with Kelsen's conceptual legal method. This led Kelsen increasingly towards the fields of politics and sociology and to a concentration upon the question of democracy and the international legal order, rather than constitutional themes. The few works in which Kelsen engages in constitutional analysis ${ }^{14}$ were of marginal interest for contemporary, American constitutional theory and were intended more for describing, to American scholars, the main features of the Austrian model of the judicial review of legislation than for the initiation of a theoretical debate on the utility of the judicial review in U.S.A. and Europe. Kelsen's work on democracy and justice $^{15}$ and the international legal order ${ }^{16}$ transformed the American aca-

${ }^{11}$ See Hans Kelsen, General Theory of Law and State (Cambridge, Harward Univ. Press, 1945).

${ }^{12}$ See, for example, Hans Kelsen, «General Theory of Law» cit., 165 et seq., 332 et seq.

13 See Laurence H. Tribe, American Constitutional Law (Mineola, The Foundation Press, 1978).

${ }^{14}$ See Hans Kelsen, «Judicial review of legislation. A comparative study of the Austrian and the American Constitution» (1942) 4 Journal of Politics 2: 183-200.

15 See, for example, Hans Kelsen «Absolutism and Relativism in Philosophy and Politics» (1948) 42 American Political Science Review 5: 906-914; Hans Kelsen, «The Natural-Law Doctrine before the Tribunal of Science» (1949) 2 Western Political Quarterly 4: 481-513; Hans Kelsen, «Foundations of Democracy» (1955) 66 Ethics 1: 1-101; Hans Kelsen, What is Justice? Justice, Law, and Politics in the Mirror of Science. Collected Essays (Berkeley/Los Angeles, University of California Press, 1957).

${ }^{16}$ See, for example, Hans Kelsen, Peace Through Law (Chapel Hill, The University of North Carolina Press, 1944); Hans Kelsen, Law and Peace in international relations. (Cambridge, Harvard University Press, 1948) 
demic position and definition of Kelsen into that of a political scientist, a scholar of political science, rather than of legal method.

Thus, the most interesting parts of General Theory of Law and State are those where he reworks and refines his gradualist theory of the sources of law ${ }^{17}$ and the parliamentary form of government, ${ }^{18}$ questions which were largely unknown to American scholars. The parts of General Theory concerning judicial decision-making are, in contrast, less interesting and have less coherence in relation to Kelsen's previous work. ${ }^{19}$ The limited acknowledgement and effect of Kelsen's work, during the period spent in the U.S.A. is also the result of the prevailing insularity of contemporaneous American scholars, manifesting itself in a lack of interest in comparative law or the new European constitutionalism. This was the period of the Cold War, of McCarthyism, when many, highly qualified and distinctive European legal scholars were present in the political science departments rather than the law departments of American Universities. The first courses and books in comparative constitutional law appeared only in the period after the 1970s, due to scholars such as Eric Stein and others. ${ }^{20}$

${ }^{17}$ See Hans Kelsen, «General Theory of Law» cit., 125 et seq.

18 See Hans Kelsen, «General Theory of Law» cit., 274 et seq.

19 See Hans Kelsen, "General Theory of Law» cit., 165 et seq. The emigration of Weimar and Austrian jurists to the U.S.A. still remains largely unexamined in the history of ideas and legal thinking, and the importance and impact that many jurists from Weimar or Austria such as Neumann, Kelsen, Fraenkel, Otto Kahn-Freund, Sinzheimer and Kirchheimer had in their new country could be better investigated: among the few works dealing with the American impact of Weimarian jurists see: on Sinzheimer, Michel Coutu, «With Hugo Sinzheimer and Max Weber in Mind: The Current Crisis and the Future of Labour Law» (2012) 34 Comparative Labour Law and Policy Journal 605-626; on Neumann and Kirchheimer, William E. Scheuerman, Between the Norm and the Exception: The Frankfurt School and the Rule of Law (Cambridge, MIT Press, 1997); on Kirchheimer and Fraenkel, Robert C. van Ooyen, Rechts- und Verfassungspolitologie bei Ernst Fraenkel und Otto Kirchheimer. Kritik und Rezeption des Rechtspositivismus von Hans Kelsen und der politischen "Freund-Feind-Theologie" von Carl Schmitt (Tyska, Verlag F. Verwaltungswisse, 2014); on Neumann, Samuel Salzborn (ed), Kritische Theorie des Staates: Staat und Recht bei Franz L. Neumann (Baden-Baden, Nomos, 2009). In Italy there is only one piece of work which has been studied with more attention: the impact of Otto Kahn-Freund on the United Kingdom's labour law, thanks to Gaetano Vardaro, «Otto Kahn-Freund e l'emigrazione dei giuslavoristi weimariani» (1982) Politica del diritto $77-100$.

${ }^{20}$ Eric Stein, Un nuovo diritto per l'Europa. Uno sguardo d'oltre oceano (Milano, Giuffrè, 1991); Eric Stein, Thoughts from a Bridge: A Retrospective of Writings on New Europe and American Federalism (Ann Arbor, University of Michigan Press, 2000); Mauro Cappelletti and William Cohen, Comparative Constitutional Law. Cases and Materials (Indianapolis, Bobbs-Merrill.1979). 


\section{KELSEN'S GOLDEN AGE AND HIS CONTRIBUTION TO CONTEMPORARY CONSTITUTIONALISM}

The emergence and significant development of Kelsen's theoretical framework can thus be situated in the reciprocal relationship between Kelsen's conception of the constitution and the political events of the newly established Austrian Republic.

Within the Kelsenian theory of constitutionalism, the specific approach to the role of the Constitutional Court became a foundational starting point for continental European scholars and students concerning the discussion of the European model for the judicial review of legislation.

\section{Committed Jurist: The Influence of Kelsen's Thought on the Austrian Constitution of 1920 and Its Defense}

The Kelsenian theory of the constitution was also one which provided the basis for an engagement in a particular defence of both the juridical form of a constitution and the notion of constitutionalism. The defence, in which Kelsen's position became increasingly polemical in character, led to the overlap with a long and well-known cultural debate about the role and the function of defending the constitution. The famous essay La garantie jurisdictionelle de la Constitution (la justice constitutionelle), published in $1928^{21}$ prompted a seminal debate between a number of the most significant European scholars of public law (such as, Berthélemy, Carré de Malberg, Duez, Fleiner, Mestre, Mirkine-Guetzévitch, Thoma, though not Eduard Lambert) ${ }^{22}$ at the Institut International de Droit Public. ${ }^{23}$

The increasingly polemical tone becomes evident in Der Staat als Integration, a long pamphlet edited in $1930^{24}$ containing the critique of Rudolf Smend's constitutional theory of 'integration' (i.e., the idea of the overcom-

${ }^{21}$ Hans Kelsen, «La garantie jurisdictionnelle de la Constitution (la justice constitutionnelle)» (1928) XXXV Revue du Droit publique et de la Science politique 197-257.

${ }_{22}$ In 1921 Eduard Lambert, the then director of the Institut de Droit Comparé in Lyon (which he founded in 1920), published his famous pamphlet Le gouvernement des juges, opposing the introduction in France, and Europe as a whole, of the American approach to the judicial review of legislation, see Edouard Lambert, Le gouvernement des juges et la lutte contre la législation sociale aux États-Unis. L'expérience américaine du contrôle judiciaire de la constitutionnalité des lois (Paris, Librairie Général de Droit et de Jurisprudence, 1921).

${ }^{23}$ Institut International de Droit Public. «Discussion du rapport de M. Kelsen sur "La garantie jurisdictionnelle de la Constitution (la justice constitutionnelle)"» (1929) Annuaire de l'Institut Internationale de Droit Public 192-201

${ }^{24}$ Hans Kelsen, Der Staat als Integration. Eine Prinzipielle Auseinandersetzung. (Vienna, Springer, 1930). 
ing of the separation between the state and society through the material integration of citizens in the values and the contents of the constitution): ${ }^{25}$ the strong critique is centred upon the incoherence of Smend's theories of integration as a theory of constitutionalism. The full intersection of polemic and theoretical analysis is realized in the later essay, Wer soll der Hüter der Verfassung sein? ${ }^{26}$ in which Kelsen, as a direct critique of Carl Schmitt's Der Hüter der Verfassung, ${ }^{27}$ provides the most strenuous defense of the position and role of the Austrian Constitutional Court. The critique centres upon the Schmittian defence of the role of the President, under the Weimar Constitution and, in relation to Article 48, in particular its conferral of emergency powers, as the effective guardian of the constitutional order.

This text is an exemplary instance of Kelsenian thought: the demonstration of sophisticated constitutional analysis combined with a subtle political realism, which maintains the distinction between law and politics while introducing the specific notion of 'Law politics', or the policy of law-making (the notion of 'Law politics' appears in the first page of the essay). ${ }^{28}$

\section{The Constitution as a Higher Law and Its Consequences}

At the origin of Kelsen's conception of the judicial review of legislation there is the assumption of the rigid character of the constitution, and the belief that the federal organization of the state must be guaranteed by the majorities who govern both the national parliament and the Länder. ${ }^{29}$

In this description, the potential affinity becomes evident with the conception of the constitution in the earlier operation of Marshall's U.S. Supreme Court, expressed in Marbury v. Madison (1803). The notion of constitutional justice (as continental Europeans call judicial review of legislation entrusted to Constitutional Courts, as a special part of the judiciary) was initially seen, in continental Europe, as an instrument for the solution of federal constitutional litigation: in short, as an arbiter of federal litigation in

${ }_{25}$ See Rudolf Smend, Verfassung und Verfassungsrecht (Munich, Duncker \& Humblot, 1928).

${ }^{26}$ Hans Kelsen, «Wer soll der Hüter der Verfassung sein?» (1931) VI Die Justiz VI $576-628$

${ }^{27}$ Carl Schmitt, «Der Hüter der Verfassung» ((March 1929) 16 Archiv für öffentliches Recht 161-237.

${ }^{28}$ See Hans Kelsen, «Wer soll der Hüter der Verfassung sein?» cit., 576. This concept re-emerged among Italian legal scholars, because of the journal Politica del diritto (published since 1970 by Il Mulino), the primary theoretical journal of the Italian realist legal movement.

29 Pedro Cruz Villalón, «La formación del sistema Europeo» cit., 232 et seq.; Gustavo Zagrebelsky, La giustizia costituzionale (Bologna, Il Mulino, 1977) 17 et seq. 
order to neutralize political conflicts. The most interesting development of constitutional justice - the protection of the constitutional and fundamental rights of individual citizens - was a gradual achievement which required a further step.

2.1. The Judicial Review of Legislation: At the Origins of the European Model of Constitutional Adjudication

The form of government of the new Austrian Republic, a purely parliamentary republic, was very different from that of the U.S.A at the beginning of the nineteenth century. A proportional electoral system based upon proportional representation, the role of mass-parties in guiding political struggle, the difficulty of reconciling 'red' Vienna and the 'white' Länder: all these factors required a distinctly different solution than the one adopted in the U.S.A.

Since the French revolutionary Constitution of $1791,{ }^{30}$ the principle of the separation of powers was interpreted by nineteenth century European constitutionalism as the exclusion or prohibition of judicial intervention in the conflicts between political bodies (in the French tradition they were entrusted to the government, in the German one - see art. 76 of 1871 federal Constitution - they were entrusted to the Bundesrat). The Kelsenian approach, in contrast, distanced itself from the prevailing doctrine of the separation of powers (for Kelsen's subsequent theoretical reflection on this doctrine), ${ }^{31}$ and recentred itself upon the juridification and political neutralization of such conflicts through the introduction of a new judicial tribunal, the Constitutional Court, whose members were nominated for life by the Federal President on the recommendation of (a) the Federal Government (six members, the President and the Vice-President) and (b) the two legislative bodies of the Federal Parliament (National Council - Nationalrat - and the Federal Council - Bundesrat), each of which recommends three members (art. 147 Austrian Const.).

The new Austrian Constitutional Court was empowered only to annul legislation declared as unconstitutional. The role of the Constitutional Court,

${ }^{30}$ See Chapitre V (Du Pouvoir Judiciare), art. 3: "Les tribunaux ne peuvent, ni s'immiscer dans l'exercice du Pouvoir législatif, ou suspendre l'exécution des lois, ni entreprendre sur les fonctions administratives, ou citer devant eux les administrateurs pour raison de leurs fonctions." On the question of the origin of the separation of powers doctrine, see Michel Troper, La separation des pouvoirs et l'histoire constitutionnelle. (Paris, Librairie Général de Droit et de Jurisprudence, 1980); Philippe Blachèr and Dominique Rousseau, Contrôle de constitutionalité et volonté générale (Paris, Press Universitaires de France, 2001).

31 See Hans Kelsen, «Die Lehre von den drei Gewalten oder Funktionen des Staates» (1924) 17 Archiv für Rechts - und Wirtschaftsphilosophie 374-408. 
as Kelsen emphasized, ${ }^{32}$ is that of a negative legislator: it may not replace unconstitutional legislation with a new, positive provision. It was, thus, a court, a judicial institution and not a political body: there was no judicial lawmaking because the substitution of the unconstitutional provision was a task for the Parliament, not for the Constitutional Court.

The Constitutional Court was also distinguished by the manner of the selection and appointment of its judges. The selection and appointment, through a process of direct nomination and election by political bodies, enabled a degree of political regulation and guarantee of the legitimacy of the Court. This process of selection and appointment was a further process of development of the continental Europe tradition. For, since the nineteenth century in continental Europe, judges were appointed as public servants, beginning their career in the special, judicial civil service at the conclusion of their initial legal studies, and were chosen by means of a public selection procedure aimed at assessing their professional ability and their knowledge of law. It is the existence of the Constitutional Court which distinguishes the Austrian Constitution from the German Weimar Constitution. ${ }^{33}$ The introduction of a Constitutional Court within the framework of the Austrian Constitution remains a central aspect of Kelsen's theoretical reflection during the 1920s. Kelsen explained to his contemporaries the importance of this institution and its centrality to a legal science of positive law in many writings published abroad such as Verfassungs und Verwaltungsgerichtsbarkeit $^{34}$ which was then subsequently enhanced by the broader theoretical exposition in La garantie jurisdictionelle de la Constitution. ${ }^{35}$ In contrast, the Reine Rechtslehre ${ }^{36}$ contains a comparatively brief discussion of constitutionalism. ${ }^{37}$

${ }^{32}$ See Hans Kelsen, «La garantie jurisdictionnelle de la Constitution» cit., Chap IV, sect. I.

${ }^{33}$ See Michael Stolleis, «Judicial Review, Administrative Review, and Constitutional Review in the Weimar Republic» (2003) 16 Ratio Juris 2: 266-280

${ }^{34}$ See Hans Kelsen «Verfassungs und Verwaltungsgerichtsbarkeit im Dienste des Bundesstates, nach der neuen österreichischen Bundersverfassung vom 1. Oktober 1920» (1923) XLII Zeischriften für schweizerischen Recht 173-217. It. Transl. «Le giurisdizioni costituzionale e amministrativa al servizio dello stato federale secondo la nuova costituzione austriaca del 1 ottobre 1920» in Hans Kelsen, La giustizia costituzionale (Milano, Giuffrè, 1981) 5-45.

35 See Hans Kelsen, «La garantie jurisdictionnelle de la Constitution» cit., 197-257.

${ }^{36}$ See Hans Kelsen, Reine Rechtslehre. Einleitung in die rechtswissenschaftliche Problematik (Wien, Franz Deuticke Verlag, 1934).

37 See Giorgio Bongiovanni, Reine Rechtslehre e dottrina giuridica dello Stato. H. Kelsen e la costituzione austriaca del 1920 (Milano, Giuffrè, 1998) and the 1928 thesis of Charles Eisenmann, La justice constitutionelle et la Haute Cour Constitutionelle d'Autriche (Paris, Economica, 1986). For a critical analysis, see Michel Troper, «Kelsen et le 
According to the logic of the Kelsenian notion of 'constitutional justice', as Kelsen explained in a famous essay that describes the new Austrian Constitution to his contemporaries ${ }^{38}$ the Austrian Constitution entrusts to the Verfassungsgerichthof (the Constitutional Court (C.C.)) the potential to review the following levels of the legal system:

- Statutes enacted by the federal parliament and legislatures of the Länder on the claim of central and regional governments (art. 140 Austrian Const.);

- Regulations having the force of law (arts. 139 and 140 Const.). This competence of the C.C. was very important because of its rules: when a tribunal believes that a regulation is unconstitutional and the question is preliminary and necessary to resolve the case, the tribunal must remit the question to the C.C. and suspend the proceedings pending the response of the C.C. The so-called "preliminary ruling" theorized by Kelsen, ${ }^{39}$ and introduced in the Austrian Constitution of 1920 , served as a model for the various forms of preliminary ruling or judgement followed by the numerous constitutions of the post-World War II era, which entrusted the control over the constitutional legitimacy of laws to their Constitutional Courts (such as the Spanish constitution of 1931; the Italian and German constitutions of 1948 and 1949 respectively; the Spanish constitution of 1978; the Portuguese constitution of 1976; and the French constitution, which by its new art. 61, after the reform of 2009, introduced the so-called exception d'inconstitutionnalité). This form of access to the judicial review of legislation (and of other quasi-legislative acts of public institutions) has become far more prevalent following the accession of many European states to the European

contrôle de constitutionalité» in Carlos-Miguel Herrera (ed), Le Droit et Le Politique: Autour de Max Weber, Hans Kelsen, Carl Schmitt (Paris, Harmattan, 1995) 157-182. Renato Treves recounts that in September of 1932 he met Hans Kelsen in Cologne, where Kelsen gave him a manuscript of a new work, see Renato Treves, «Prefazione» in Hans Kelsen (ed), Lineamenti di dottrina pura del diritto, (Torino, Einaudi, 1967) 12. This manuscript was then translated into italian by Treves and published in the journal Archivio Giuridico in 1933, before the publication of the German edition (see Hans Kelsen, «La dottrina pura del diritto. Metodo e concetti fondamentali» (1933) XXVI Archivio Giuridico 121-171). Kelsen had intended to emigrate from Germany and sought the translation of his works into languages other than German. According to Treves, the first version of Reine Rechtslehere in 1933 was published, in addition, in Spanish, Swedish, Flemish and other European languages.

${ }^{38}$ See Hans Kelsen, «Verfassungs und Verwaltungsgerichtsbarkeit im Dienste des Bundesstates» cit., 5-45.

${ }^{39}$ Hans Kelsen, «La garantie jurisdictionnelle de la Constitution» cit., Cap. V. 
Union. Judges of every Member State of the European Union are aware of this capacity to review national legislation in relation to its conformity to relevant provisions of European Union Treaties: the preliminary rulings originally provided for by art. 177 (then subsequently defined in art. 234, and now, after Lisbon, art. 267 of the Treaty) have the same form (the difference is located in the reference to the Treaties rather than the provisions of the national constitution) as the original Kelsenian conception of preliminary rulings;

- Direct claims of citizens against administrative acts alleging the violation of constitutional rights, conditional upon the previous failure of all ordinary claims (art. 144 Const.): this way of access was also decisive for the development of the European model of constitutional justice, being the prototype for all forms of direct claim (the Spanish amparo constitucional in the Constitutions of 1931 and 1978; the German Verfassungsbeschwerde introduced in 1949 and other similar forms of access to Constitutional Court which are widespread in Europe) ${ }^{40}$

- Competency and jurisdictional conflicts between judges and administrative bodies and among judges in different judicial fields (civil, administrative, etc.) (art. 138 Const.);

- Criminal charges and proceedings (art. 142 Const.) against the federal president, and the members of national and local government, in order to exclude every form of immunity of the governmental powers from prosecution (the notion of the rule of law (Rechtsstaat)).

It is very difficult, if not impossible, to determine, in detail, the direct contribution of Kelsen's thought to each one of these features of the Austrian model of constitutional justice. ${ }^{41}$

Beyond the question of filiation, Kelsen's decisive and enduring contribution to the genesis and diffusion of a juridical conception of constitutional justice is evident in the contemporary form of European constitutionalism

${ }^{40}$ For Kelsen's opinion about the direct claim see Hans Kelsen, «Verfassungs und Verwaltungsgerichtsbarkeit im Dienste des Bundesstates» cit., 29 et seq.

${ }^{41}$ See the spectrum of positions exemplified by Theo Öhlinger, «Verfassungsgerichtsbarkeit und parlamentarische Demokratie» in Heinz Schäffer (ed), Im Dienste an Staat und Recht. Festschrift für Erwin Melichar (Wien, Manz Verlag., 1983) 125-148; Theo Öhlinger, «The Genesis of the Austrian Model» cit., 206-222; Stanley L. Paulson, «On Hans Kelsen's Role in the Formation of the Austrian Constitution and his Defense of Constitutional Review» in Werner Krawietz, Robert S. Summers, Ota Weinberger and Georg Henrik von Wright (eds), The Reasonable as Rational? Festschrift for Aulis Aarnio (Berlin, Duncker \& Humblot, 2000) 385-395; Georg Schmitz, «Die Vorentwürfe Hans Kelsens» cit.; Georg Schmitz, «The Constitutional Court of the Republic of Austria 1918-1920» (2003) 16 Ratio Juris 2: 240-265. 
whose foundations remain embedded in a Kelsenian form of constitutional justice. ${ }^{42}$ The subsequent creation and practice of different European constitutional courts (including the more recent experience of the European Court of Justice), has led to further, significant developments in European legal thought concerning constitutional justice. Legal scholars considering the notion of constitutional justice in the Constitutions of the interwar era (see, in particular, art. 19 Const. Weimar, arts. 138 and 140 Const. of Austria, arts. 100 and 121 Spanish Const. of 1931) introduced the distinction between the two different functions of constitutional justice: the solution of conflicts among the organs of the State, the so-called Staatsgerichtsbarkeit, and the function of the so-called Verfassungsgerichtsbarkeit, which was developed in Austria, following Kelsen's initial indications. ${ }^{43}$

The function of Staatsgerichtsbarkeit flows from the conception of the Constitution as a norm of the organization of relations between powers, i.e., the various organs or bodies of the State (this function derives its particular importance from a state which has a federal or regional structure involving the existence of many legislators in potential competition one with the other); the function of Verfassungsgerichtsbarkeit is derived from a conception of constitutional justice as a means of protecting the constitutional rights of citizens against the legislator and the decisions of the political majority.

In the post- World War II era we witness the diffusion of complete systems of constitutional justice that contain both the functions of Staatsgerichtsbarkeit and Verfassungsgerichtsbarkeit, in order to ensure and guarantee an enhanced legitimacy and effectiveness of the constitutional order. This occurred in Italy, Germany and Austria, then in Spain, Portugal, Belgium, France and, more recently, in the initial constitutional frameworks of the former communist countries of Central and Eastern Europe, such as Bulgaria, Czech Republic, Hungary, Poland and Ukraine (followed by those states arising from the collapse of the Federal Republic of Yugoslavia). The increasing generalization of this form of constitutional justice within Europe, centred upon a Constitutional Court, has been accompanied by a migration or transplantation to other continents, especially to Latin and Central America but also Africa and Asia, all countries where the Kelsenian foundation for constitutional justice was preferred to that contained in the U.S. model. ${ }^{44}$

${ }^{42}$ Mauro Cappelletti, Il controllo giudiziario di costituzionalità delle leggi» cit., 112; Alessandro Pizzorusso, «I sistemi di giustizia costituzionale» cit., 522.

43 Alessandro Pizzorusso «Sub Art. 134 Cost.» in Commentario della Costituzione a cura di G. Branca e A. Pizzorusso. Garanzie costituzionali (Bologna-Roma, Zanichelli, 1981) $1-143,17$ et seq.

${ }^{44}$ Louis Favoreu, Les cours constitutionnelles (Paris, PUF, 1986) 11 et seq.; Lucio Pegoraro, Giustizia costituzionale comparata. Dai modelli ai sistemi (Torino, Giappi- 
This diffusion of the Kelsenian model of constitutional justice was accompanied by a further development: the recentering of attention upon the enhancement and consolidation of the function of Verfassungsgerichtsbarkeit (the decision on the constitutionality of statutes and acts that have to be applied in a pending judicial determination) rather than upon the function of Staatsgerichtsbarkeit, in which the constitutional court acts as an arbiter of conflict - cases of litigation - between the institutions and bodies within the existing constitutional framework.

The possibility of this recentring of attention in the future development of constitutional justice is already acknowledged in La garantie jurisdictionelle de la Constitution. ${ }^{45}$ As he foresaw in this work, the control of the constitutionality of laws undertaken by constitutional courts may have two different objects: formal constitutionality, that is the correspondence of the statute or controlled act to procedural norms contained in the Constitution; and material constitutionality, namely, the correspondence of the statute or controlled act to the material content of the various constitutional norms. It is material constitutionality which reopens the constitution to the potential influence of politics, through general notions of 'freedom', 'equality' and 'justice', ${ }^{46}$ and renders it susceptible to different interpretations typical of the content of the constitutional provisions, even when 'long' and more complex, sophisticated constitutions affirm specific fundamental rights (such as economic, labour and welfare rights). The more extensive and detailed the economic and welfare rights (often corresponding to politically opposite views of life) contained in a constitution, the more difficult the process of constitutional interpretation and the use of these constitutional provisions as a basis to determine the unconstitutionality of a statute. This difficulty, created by material constitutionality, is at the origin of the explicit Kelsenian opposition to the presence and expansion of programmatic constitutional norms, which are considered as undermining and rendering incoherent the value-free concept of the constitution. ${ }^{47}$

The position of overt Kelsenian opposition has, however, been displaced through the collaboration of constitutional courts and ordinary judges ${ }^{48}$ in

chelli, 2015) Chap. II, sect. 1; Alessandro Pizzorusso «Sub Art. 134 Cost.» cit., 22 et seq.; Dominique Rousseau, La justice constitutionnelle en Europe (Paris, Montchrestien, 1998); Christian Starck, Albrecht Weber, and Otto Luchterhandt (eds), Verfassungsgerichtsbarkeit in Mittel- und Osteuropa (Baden Baden, Nomos, 2007).

${ }^{45}$ See Hans Kelsen, «La garantie jurisdictionnelle de la Constitution» cit., 197-257.

${ }^{46}$ Hans Kelsen, «La garantie jurisdictionnelle de la Constitution» cit., 242.

${ }^{47}$ Carlo Mezzanotte, Corte costituzionale e legittimazione politica (Roma, Tipografia Veneziana, 1984) 140 et seq.

48 A similar process is evident, as a result of the existence and effect of European Court of Justice (ECJ) preliminary rulings. For evaluation of the relationship between the 
which constitutional justice has come to assume a decisive role in implementing the fundamental rights of citizens. The displacement has been conceived as a further development, rather than a fundamental break with the Kelsenian position, by many continental European scholars, such as Alessandro Pizzorusso, Louis Favoreu, and Francisco Rubio Llorente. For them, constitutional justice, in the version originally theorized by Kelsen and its subsequent evolution in many European countries, is the major novelty of European constitutional law in the second half of the twentieth century. ${ }^{49}$

In relation to this further development, German and Italian scholars ${ }^{50}$ introduced an additional classificatory distinction within the juridical framework of constitutional justice when it deals with the control of the constitutionality of legislation: the distinction between Abstraktenormenkontrolle and Konkretenormenkontrolle. The notion of Abstraktenormenkontrolle refers to regulation, by the Constitutional Court, whose object is that of 'provisions', i.e., the law as stated by the legislator. In contrast, the notion of Konkretenormenkontrolle refers to regulation whose object is a 'norm', i.e., the law at the moment of its interpretation and application to a particular case (in this sense, concrete). Thus, the distinction also represents different degrees of potential politicization of constitutional decisions. For situations of Konkretenormenkontrolle are less open to political influence than those situations of Abstraktenormenkontrolle, when constitutional decisions are not preliminary to a concrete case pending judicial determination, and in which there is there is a substantial risk of politicized decision-making, which would minimize the authority of the Constitutional Court. Hence, the effectiveness and legitimacy of constitutional justice is comparatively greater when the Constitutional Court acts to resolve a concrete controversy. These considerations, however, demonstrate the continued importance and pertinence of Kelsen's theories of constitutional justice; and, also, they

judges of the ECJ and judges of EU Member States concerning the provisions and application of domestic law within the framework of European law see, Joseph H.H. Weiler, Il sistema comunitario europeo (Bologna, Il Mulino, 1985) 217 et seq.; Giuseppe Martinico, L'integrazione silente. La funzione interpretativa della Corte di Giustizia e il diritto costituzionale europeo (Napoli, Jovene, 2008) 48 et seq.

49 See Louis Favoreu, «Le droit constitutionnel, droit de la Constitution et constitution du droit» (1990) I Revue française de droit constitutionnel 71-99, 73 et seq.; Francisco Rubio Llorente, «El Tribunal Constitucional» (2004) 71 Revista española de derecho constitucional 11-33, 11; A. Pizzorusso, La costituzione ferita (Roma-Bari, Laterza, 1999) 40 et seq.

${ }^{50}$ Alessandro Pizzorusso, «I sistemi di giustizia costituzionale» cit., 527 et seq.; Ernst Friesenhahn, Die Verfassungsgerichtbarkeit in der Bundesrepublik Deutschland (Köln, Heymanns, 1962), It. transl: La giurisdizione costituzionale della repubblica Federale Tedesca (Milano, Giuffrè, 1973) 63 et seq., 67 et seq. 
explain why continental European scholars often refer to a definition of the European model of constitutional justice as the Kelsenian model. ${ }^{51}$

\subsection{The Gradualist Theory of the Sources of Law: The Stufenbau}

The second aspect of the continued relevance of Kelsenian legal theory for contemporary constitutionalism concerns the theory of the Stufenbau, the systematic construction of a dynamic hierarchy of legal norms from the sources of law. The notion of the Stufenbau is an avowedly theoretical concept and, thus, more abstract than the Kelsenian concept of constitutional justice. The theory of the Stufenbau is itself a foundational element of Kelsenian legal science and predicated upon a presupposition of the essential logical coherence and unity of a system of positive law. The influence of this notion upon contemporary constitutionalism has been, as a result, more indirect and reflected in the general orientation of scholars' legal thinking rather than in the indication and formulation of concrete solutions. From this, derives the frequent characterization of Kelsenian legal science - in particular, by those legal scholars orientated by the alternative tradition of legal realism - as the so-called normativist approach distinguished by an excessive, empty formalism..$^{52}$

The Kelsenian theory of the Stufenbau, which is an appropriation of the original theory in the work of Adolf Merkl, ${ }^{53}$ is provided with its most comprehensive elaboration in three works: the first, the Reine Rechtslehre. Einleitung in die rechtswissenschaftliche Problematik (1934), published after the collapse of the First Austrian Republic's constitutional framework, during Kelsen's exile, then, after his encounter with American law, the General

${ }^{51}$ See, for example, Louis Favoreu, «Les cours constitutionnelles» cit., 11; Alessandro Pizzorusso «Sub Art. 134 Cost.» cit., 23.

${ }^{52}$ See, for example, Giuseppe Capograssi, «Impressioni su Kelsen tradotto» (1952) 4 Rivista trimestrale di diritto pubblico 767-810; Silvana Castignone, «"Il grande mistero di Hans Kelsen". Validità ed efficacia nel formalismo kelseniano e nel realismo scandinavo» (2008) 2 Materiali per una storia della cultura giuridica 347-356; Angelo Falzea, Introduzione alle scienze giuridiche: il concetto del diritto (Milano, Giuffrè, 2008) 274 et seq.; Carl Schmitt, Staat, Bewegung, Volk. Die Dreigliederung der politischen Einheit (Hamburg, Hanseatische Verlagsanstalt, 1935) It. transl. Un giurista davanti a se stesso. Saggi e interviste a cura di Giorgio Agamben, (Vicenza, Neri Pozza, 2005) 253-312, 270 et seq.; Francesco Viola, «La teoria della separazione tra diritto e morale» in Studi in memoria di Giovanni Tarello (Milano, Giuffè, 1990) vol. II, 667-705, 684 et seq.

${ }^{53}$ See Martin Borowski, «Die Lehre vom Stufenbau des Rechts nach Adolf Julius Merkl» in Stanley L. Paulson and Michael Stolleis (eds), Hans Kelsen - Staatsrechtler und Rechtsphilosoph des 20 Jahrhunderts (Tübingen, Mohr-Siebeck. 2005) 122-159; Stanley L. Paulson, «How Merkl's Stufenbaulehre Informs Kelsen's Concept of Law» (2013) 21 Revus 29-45. 
Theory of Law and State (1945) and, finally, the revised second edition of the Reine Rechtslehre (1960).

The notion of the Stufenbau arises from the conception of the legal system of positive law as a system of norms: there is a coherent order in the relationship between the different sources and this order is conferred by the notion of the Stufenbau which allows the arrangement of these sources in a hierarchical system. The hierarchy, commencing from the logical presupposition of a final, superior norm (Grundnorm), is the condition for the conferral of validity upon each of the subsequent inferior, but increasingly concrete normative orders: a top-down approach from the most abstract, fundamental norm (Grundnorm) to the constitution, then to legislative norms or statute law, then to executive regulations and general administrative acts and, finally, to the most concrete level of judicial or administrative decision-making.

The Stufenbau theory is fundamental to the comprehension and description of the functioning of European federal and regional legal system, as it is not based on a rigid separation of competences as in American federalism: the constitution is the very condition of validity of all primary norms (both of the central state and of the decentralized entities, whatever their designation, e.g., Länder, Regions, member states, etc.), since it has the Kompetenz-Kompetenz (the capacity to determine the extent of its own competence), thereby establishing the condition of validity of enacted legislation (generally through the specific enumeration of the matters which are entrusted to the legislative powers of the central state or decentralized entities, or to both). ${ }^{54}$

The theory of the Stufenbau enables the understanding of the operation of the system of positive law composed of a number of sources of law, especially in a multilevel legal system characterized by a rigid constitution. During the nineteenth century, when constitutions were characterized by a general flexibility and lack of rigidity, the interpretation of statute law, together with the resolution of the contradictions among different sources, was entrusted to two main principles: the temporal principle (the criterion of the prevalence of the will of the most recent legislator) and the criterion of specialty (that is an exception to the former: special statutes are not abrogated by the subsequent succession of general statutes), with their corollaries (the central principle being that of the prohibition of ex post-facto laws). The hierarchy principle was of secondary importance, and it was relevant only in the

${ }^{54}$ See Paolo Carrozza, «Central Law and Peripheral Law» in Alessandro Pizzorusso (ed) Law in the Making. A Comparative Survey (Berlin, Springer, 1988) 238-274; Paolo Carrozza, «I rapporti centro - periferia: regionalismi, federalismi e autonomie» in Paolo Carrozza, Alfonso Di Giovine and Giuseppe F. Ferrari (eds), Dritto costituzionale comparato (Roma-Bari, Laterza, 2014) 894-951. 
case of contrast between a statute and a regulation, with primacy accorded to the former in recognition of the parliamentary form of government.

However, in multilevel legal systems, based on written and rigid constitutions, the two preceding criteria of interpretation are no longer sufficient because the relationship between the sources of law is dominated by principles of hierarchy and competence. In order to explain the multilevel government and organization of powers, typical of federal and regional states, or the phenomenon of the European Union, the Kelsenian notion of the Stufenbau is essential to describe these relationships of the sources of law, and to resolve the apparent contradictions and contrasts in the application and interpretation of the law: this is the general, indirect legacy of Kelsen's thought.

The general, indirect legacy of the Kelsenian notion of the Stufenbau is also apparent in the rarity of detailed quotation from Kelsen's work in contemporary handbooks of consitutional law. In relation to the Stufenbau, its continued presence is one of general orientation and citation rather than detailed textual analysis and quotation..$^{55}$

The presence of the Kelsenian theory of the sources of positive law in contemporary constitutional law is also to be found in the famous debates which revealed important divergences and disagreements amongst Spanish and French scholars. An example is the pamphlet of Eduardo Garcia de Enterrìa, La Constitución como norma y el Tribunal Constitucional, ${ }^{56}$ which contains a series of arguments against his Spanish colleagues who, after the promulgation of the 1978 Constitution, continued to refer to constitutional law as derecho politico, maintaining both the continuity with the old disciplinary designation of Francoist era and a prevalent politological approach to the study of constitutional law. Another example is the struggle of Louis Favoreu for a Nouveau Droit constitutionnel, against the so-called duvergerisme, designating the approach of the French political scientist Maurice Duverger, ${ }^{57}$ and the revolution in the study of public law introduced in France, in 1954 (décret 27 March 1954, n. 343), which sought to merge political science and constitutional law in the new university course of Institutions de Droit public et de la Science politique. ${ }^{58}$

${ }_{55}$ See, for example, Ignacio de Otto, Derecho constitucional. Sistema de Fuentes (Barcelona, Ariel, 1988); Alessandro Pizzorusso, Delle fonti del diritto. Commentario del Codice Civile Scialoja - Branca (Bologna-Roma,: Zanichelli-Il Foro Italiano, 2011); Vezio Crisafulli, Lezioni di diritto costituzionale. L'ordinamento costituzionale italiano. Le fonti normative. La Corte costituzionale (Padova, Cedam, 1978). See, also, in relation to the comparative survey of the sources of law, Alessandro Pizzorusso, Law in the Making» cit.: Kelsen is still the most cited author.

56 Eduardo Garcìa de Enterrìa, «La Constitución como norma» cit.

57 Maurice Duverger, Les partis politiques (Paris, A. Colin, 1951).

${ }^{58}$ Louis Favoreu, «Le droit constitutionnel, droit de la Constitution» cit., 73 et seq. 


\section{KELSEN AND POST-MODERN CONSTITUTIONALISM}

The preceding overview has indicated the significant presence and relevance of the Kelsenian position in the constitutional thought of post-World War II continental Europe which extends far beyond the borders of German-speaking countries. The further question which remains to be clarified is the extent to which the Kelsenian position remains a conceptual resource of continued relevance for the future. The question becomes that of the extent to which Kelsen's work continues to provide a set of conceptual instruments with which to confront the crisis of contemporary constitutionalism, which is itself strictly connected to the crisis of state sovereignty and an autonomous domain of state or domestic law, resulting from the emergence and increasing proliferation of supra-national and global law.

\section{The Importance of Kelsen's Thought for the Legal Understanding of Multi-level Government (Monism v. Dualism)}

The continued utility of the Kelsenian approach (and, in particular, of the Stufenbau theory) has been an integral element of my work in order to explain that what appears to many international lawyers as a typical matter of international law (the European Union's secondary norms and their relations with the legal orders of member states) as one which could be better explained as a problem of constitutional law. ${ }^{59}$ If one considers the European Union as a complex and composite legal system and the sources of law (both European and domestic) as sources of a unique legal system, Kelsen's Stufenbau theory offers a convincing argument to resolve the question of the normative coherence and potential conflict or interference between European law and Member states' law: the European Union legal system is not superior to Member states' legal systems but has supremacy. The separation among legal systems is defined by a separation of competences contained in the Treaties. Thus, in the event that the European Law is competent, it is valid and it has supremacy over the non-competent and, therefore, inconsistent law of the Member states.

It was the European Court of Justice which created, and continues to repeat a mistaken legal definition when it declared as inconsistent with European law any domestic law in potential conflict with the Treaties and applies to European law to the particular case. It would be better for it not to speak about supremacy but, rather, about a lack of competence of the legislators of Member states, due to the fact that Treaties have accorded competence in the

${ }^{59}$ Paolo Carrozza, «El "multilevel constitutionalism" y el sistema de Fuentes del derecho» (2006) 19 Revista española de Derecho Europeo 341-366, 351. 
matter to European law and the Member states have provided consent that (valid, competent) European law has direct effect in their respective legal orders, thus prevailing over their domestic law (regardless of whether this law is enacted through the form of a directive or a regulation).

It is a question of competence, not of hierarchy, ${ }^{60}$ hence, it becomes a question of constitutional law and not of international law. The adoption of the criteria of competence and of interpretation of the relationship between sources of law enables the unproblematic comprehension of the presence, within the European Union, of the following:

- Three orders of legislators: the European legislators (Council, Parliament); the member states' legislators, the legislators of the decentralized entities of each member state (this depends on the form of state of each country, according to the respective constitution). The competence of each one of these legislators is defined by the rules on competence established by the European Treaties and the Constitutions of Member states.

- Four or five governments: the European government (the Commission); the Member states' national governments, the governments of Länder, regions and other decentralized entities; and the governments of local authorities (whose designation is dependent the constitutions of member states).

- Various levels and orders of administrative bodies: firstly, the European Union's (even if European law is executed in the form of administrative acts by the administration of the Member states: the Kelsenian question of Bundesexecution; ${ }^{61}$ and, secondly, two or three levels of administrative organizations in each state, depending upon their degree of decentralization.

- Two orders of judicial power: that of the European Union and each Member state.

These orders are integrated when the subject matter of the controversy is the application of European law as a result of the operation of the device of the preliminary ruling. In relation to these considerations, it is a purely academic and possibly futile debate to affirm state sovereignty since the Constitution of each member state delegates powers to the European Union,

${ }^{60}$ Using Kelsen's categories, see Hans Kelsen «Verfassungs und Verwaltungsgerichtsbarkeit im Dienste des Bundesstates» cit., 21 et seq.

${ }^{61}$ See Hans Kelsen, «Die Bundesexekution. Ein Beitrag zur Theorie und Praxis des Bundesstaates, unter besonderer Berücksichtigung der deutschen Reichs- und der österreichischen Bundes- Verfassung» in Zaccaria Giacometti and Dietrich Schindler (eds) Festgabe für Fritz Fleiner zum 60.Geburtstag (Tübingen, J.C.B. Mohr, 1927) 127-187. 
through the adhesion to the Treaties: the question of potential conflict and interference between European law and Member states' law cannot be resolved as a problem of international law and of state sovereignty, because it is entrusted to the judges of each Member state.

Beyond this question, there arises the further one of the nature of a single, legal order, as suggested by Kelsenian monism: this has elicited a significant and varied response..$^{62}$ In relation to these existing responses, it is possible to consider introducing the notion of a Federalizing process: a return to, and appropriation of, the notion of Carl J. Friedrich which itself originates from a reflection upon U.S. federalism, orientated to institutional dynamics rather than a static constitutionalism. ${ }^{63}$ This is, of course, to have recourse to notions of political science and to acknowledge that the definitions of a political scientist are, in certain instances, more useful than those of scholars of constitutional and international law. A process of gradual integration, such as the European one, is correctly defined as a Federalizing the notion of process, since it cannot be classified with the classic conceptual figures of constitutional and international law, which is based on a state-centred approach to the dimensions of political and legal power. ${ }^{64}$

The adoption of the Kelsenian position, which insists upon monism in international law and its determination of the approach to the relations among the sources of law, furnishes the theoretical interpretation of the results of this process of normative integration as a unique legal order. This, in turn, constitutes the theory as the description of the presuppositions (legal cognition) of domestic judges, who are obliged, when dealing with a case concerning the application of European law, to ensure that European law necessarily prevails over any domestic law that is inconsistent with it.

\section{The Globalization of Constitutionalism: Is an Open- Ended Constitutionalism Possible?}

The increasing prevalence of the process of globalization and its associated political and legal pluralism constitutes an equally important manner in

${ }^{62}$ Giuseppe Martinico, The Tangled Complexity of the UE Constitutional Process. (London, Routledge, 2013) 19 et seq.

${ }^{63}$ Carl J. Friedrich, Constitutional Government and Politics. Nature and Development (New York, Harper, 1950) It. Transl. Governo costituzionale e democrazia (Vicenza, Neri Pozza, 1950) 274 et seq.

${ }^{64}$ For Friedrich's later application of this concept to European integration, see Carl J. Friedrich, «Federal Constitutional Theory and Emergent Proposal» in Arthur W. Machmahon (ed) Federalism. Mature and Emergent (New York, Russell \& Russell, 1962) $510-532$. 
which the Kelsenian position retains its continued contemporary pertinence. For, the value-free Kelsenian conception of constitutionalism offers valuable insights into the legal pluralism which has emerged from the dynamics of globalization. ${ }^{65}$ In particular, the crisis of constitutionalism resulting from globalization and the development of supranational law, displaces the conventional explanatory framework of a concept of constitutionalism based on the legal and political dimensions of the state and its absolute sovereignty.

The analytical framework is constructed in three stages. First, that a focus upon domestic constitutional reform - an attempt that many countries are pursuing in order to solve the constitutional crisis - is useless and unnecessary, since the great crisis of our societies and economies in the new era of globalization does not have an exclusively national (and, thus, constitutional) dimension but a necessarily a global or supra-national dimension. ${ }^{66}$

Rather, the focus should be upon the collaborative development and implementation of long-term and coordinated policies among states (for example, the introduction of the Euro, the inclusion of Eastern countries in the European Union, etc.). The project of a reform, at the level of the national constitution, retains its utility only if it becomes the expression of progressive achievements, namely, as a form of consolidation, the comprehensive representation of a processes of transformation already realized by other (ordinary, non-constitutional) means.

The strictly Kelsenian response would be to consider a new instance of the first stage of concretization of the fundamental or basic norm (Grundnorm): a new constitutional (but not state) order. Yet, the question which immediately arises is that of what exactly can be, at present, a new fundamental norm at the state level? For, only a revolution, or the earthquake generated by World War (for democratic constitutions), or a coup d'état (for authoritarian constitutions) or the proletarian revolution (for socialist constitutions) could justify the rise of constituent power and, consequently, of a constituent assembly ... [and of a new constitutional order; so that] ... it is no surprise that the most recent seismic movement in European constitutionalism was precipitated by the demise of communist regimes in East Europe after the fall of the Berlin Wall. ${ }^{67}$

The second stage involves the recognition that the crisis of the classical model of western constitutionalism reveals itself in the form of the crisis of

${ }^{65}$ Paolo Carrozza, «Constitutionalism's post-modern opening» in Martin Loughlin and Neil Walker (eds), The Paradox of Constitutionalism (Oxford, Oxford University Press, 2007) 169-187, 184 et seq.

${ }^{66}$ See Petra Dobner and Martin Loughlin, The Twilight of Constitutionalism? (Oxford, Oxford University Press, 2010).

${ }^{67}$ Paolo Carrozza, «Constitutionalism's post-modern opening» cit., 174. 
value-oriented constitutions, with the consequent crisis of judicial review and constitutional adjudication. This is evident, in particular, in 'long' and value-orientated constitutions, in which these values respond to conflicting political programmes, and the legislation cannot be configured as a mere technical implementation or application of the constitution. Here, the pertinence of an element of the Kelsenian position re-emerges in its designation of the essentially problematic character of value-oriented and programmatic constitutional norms.

It is the crisis of constitutional norms magis ut valeant, as a system of effective norms directly binding political actors: ${ }^{68}$ at present, the value-oriented constitutions lack a clear framework of values and principles translated into a hierarchically ordered system of positive provisions upon which courts (and political actors) can base their decisions. In order to overcome these difficulties, courts are forced to ground their decisions either on a balancing test (whose validity is restricted to a single case and cannot confer a more comprehensive or general validity) or on politically neutral constitutional principles, such as the rationality of means (reasonableness, proportionality, Verhältnismäßigkeit). ${ }^{69}$

The combination of these two stages produces an understanding of contemporary constitutionalism as marked by an essential openness. From this emerges the final stage, the delineation of this phenomenon of openness of contemporary constitutionalism and, in particular, the question of whether it consists in the flexibility of constitutional norms and their ability to be used as open provisions, which requires not an implementation or application, but a continuous integration through the political process. Is this, then, the triumph of Kelsenian relativism, of Kelsen's value- free idea of the constitution? Or, is this openness one which requires a constitution that adjusts and modifies itself, following Schumpeter, ${ }^{70}$ and Dahl, ${ }^{71}$ the theorists of the procedural democracy, merely through an electoral procedure in order to elect the governors?

The response to this dilemma cannot be simple and immediate, but requires considered reflection. For some Italian scholars, such as Zagrebelsky ${ }^{72}$ and

${ }^{68}$ The maxim is that of Mario Dogliani, Interpretazioni della Costituzione (Milano, Angeli, 1982) 65 et seq.

${ }_{69}$ Gustavo Zagrebelsky, Il diritto mite. Legge, diritti, giustizia (Torino, Einaudi, 1992) 147 et seq.; Mario Dogliani, «Interpretazioni della Costituzione» cit., 75 et seq.; Carlo Mezzanotte, «Corte costituzionale e legittimazione politica» cit., 140 et seq.

70 Joseph A. Schumpeter, Capitalism, Socialism and Democracy (London, Allen \& Unwin, 1942), Chap. 22.

${ }_{71}$ Robert A. Dahl, Democracy and its Critics (New Haven, Yale University Press, 1989) It. transl. (1990) La democrazia e i suoi critici (Roma, Editori Riuniti, 1990) 201 et seq.

${ }^{72}$ Gustavo Zagrebelsky, «Il diritto mite» cit. 
Spadaro, ${ }^{73}$ the answer is not constitutional relativism and value-free constitutions but, rather, the diffusion of a continuous aspiration to live together in order to facilitate the cohabitation of principles and values which, if conceived in an absolutist way, would be irreconcilable (Zagrebelsky's 'mild law'); or, alternatively, a re- awakening of the political system to a superior order of justice and equality. ${ }^{74}$

This response, which is beyond the reaffirmation or rearticulation of relativism, represents the idea of a weak constitutionalism; and with it, the potential indication of a broader, fundamental change: the tradition of modern western constitutionalism has been comprehensively relinquished. In relation to the increasing marginalization of this tradition, it is unnecessary to regret the current position of modern constitutionalism or to undertake its transformation into these forms of weak constitutionalism. Rather, it requires a far more significant opening of our constitutionalism to 'others', in particular, when these 'others' have a very different conception of life, cohabitation and a legal order. Thus, an overtly expansive, open constitutionalism encompasses the totality of unwritten norms which furnish the conditions for dialogue among different cultures and perspectives in a globalized society: constitutional norms are thereby redefined as those which enable both recognition of the other and of her/his values and principles. ${ }^{75}$ It is, therefore, dialogue, not relativism (whether Kelsenian or post-modern) which is the path to the conceptual understanding and analysis of the contemporary openness of western constitutionalism. The notion of dialogue contains the elements of modification or renunciation of existing positions and concessions to others. It is a process of integration based on sharing knowledge and acceptance of others, not of assimilation. In this, it marks the explicit rejection of all forms of coercion or forcible imposition, and indicates its break with the history of encounters with other cultures originating in the European 'discovery' of the New World, which Europeans considered only as an object of conquest and subjugation. ${ }^{76}$ The dialogic basis of open constitutionalism is possible since, in a constitutionalism that becomes increasingly less national and more supranational or, rather, transnational and intercultural or global, the most important juridical event is the proliferation of charters of human and fundamental rights, many of which are accompanied by specifically designated supra-national or international courts.

73 Antonino Spadaro, Contributo per una teoria della costituzione. I. Tra democrazia relativista e assolutismo etico (Milano, Giuffrè, 1994).

${ }^{74}$ Antonino Spadaro, «Contributo per una teoria della costituzione» cit., 318 et seq.

${ }^{75}$ Gianluigi Palombella, È possibile una legalità globale? Il Rule of Law e la governance del mondo (Bologna, Il Mulino, 2012) 151 et seq.

76 Tzvetan Todorov, La conquista dell'America. Il problema dell'altro (Torino, Einaudi, 1994) 225 et seq. 
The dialogue among international, supra-national and domestic Courts is gradually replacing the lack of a global political authority capable of creating an effective political and legal order (if it will ever assume a concrete existence) common to every people, since this dialogue is directed to the elaboration and development of a new global constitutional law based upon the presumption of equality of citizens' rights.

This is a development whose evolution is still in progress, and it is impossible to predict either when it will be concluded or the final result at the conclusion of the process: but the indications are that it will be very different from Kelsen's conception of a legal order and constitutional justice, strictly connected with the state- centred dimension of the political and legal order, and also very far from the monistic idea of the primacy of international law that Kelsen sought to articulate in his later work. ${ }^{77}$ This is, however, not to subscribe to the increasing redundancy of the Kelsenian position, but to adopt an interpretative stance towards Kelsen's work which is one of selective appropriation.

In relation to the crisis of domestic, state-centred constitutionalism this selective appropriation requires that one relinquish the return to a value-free constitutionalism, but also adherence to the subsequent theory of weak constitutionalism which permits the openness of our societies to 'others' without requiring the maintenance of a political and legal order based upon the belief, or hope, in a superior and common idea of justice.

A new open constitutionalism, a global rule of law, is, instead, emerging through a process of dialogue between very different legal systems and their courts and through the recognition of the rights of the others: it consists of all the norms that allow the recognition of the others in order to gradually construct a common order acceptable to all people. If this process of patient and gradual construction of common constitutional values requires compromise and the concomitant reciprocal renunciation or modification of positions and perspectives, then we will continue to be much more Kelsenian than we believe we are.

77 See Hans Kelsen, «Peace Through Law» cit., Part I; Hans Kelsen, «General Theory of Law» cit., 332-367; Hans Kelsen, «Law and Peace in international relations» cit. 


\title{
KELSEN AND CONTEMPORARY CONSTITUTIONALISM: THE CONTINUED PRESENCE OF KELSENIAN THEMES
}

\author{
Kelsen y constitucionalismo contemporáneo: \\ la continua presencia de los temas kelnesianos
}

\author{
Paolo Carrozza \\ Full Professor of Constitutional Law \\ Scuola Superiore Sant'Anna, Pisa \\ paolo.carrozza@sssup.it
}

http://dx.doi.org/10.18543/ed-67(1)-2019pp55-82

\section{Copyright}

Estudios de Deusto es una revista de acceso abierto, lo que significa que es de libre acceso en su in tegridad. Se permite su lectura, la búsqueda, descarga, distribución y reutilización legal en cualquier tipo de soporte sólo para fines no comerciales, sin la previa autorización del editor o el autor, siempre que la obra original sea debidamente citada y cualquier cambio en el original esté claramente indicado

Estudios de Deusto is an Open Access journal which means that it is free for full access, reading, search, download, distribution, and lawful reuse in any medium only for non-commercial purposes, without prior permission from the Publisher or the author; provided the original work is properly cited and any changes to the original are clearly indicated. 